\title{
Examination with the thermographic systems of the living body physiological reaction on the thermal stimulation
}

\author{
by A. Trafarski*, R. Rutkowski** P.Korman ${ }^{* *}$, L. Różański** and A.Straburzyńska-Lupa ${ }^{* \star}$ \\ * Kazimierz Wielki University in Bydgoszcz, J.K. Chodkiewicza str. 30, 85-064 Bydgoszcz, Poland, \\ andrzej.trafarski@gmail.com \\ ** University School of Physical Education in Poznan, Droga Dębińska str. 10c, 61-555 Poznań, Poland, \\ rutkowski@awf.poznan.pl,simskor@interia.pl, a.straburzynskalupa@gmail.com \\ *** Poznan University of Technology, Piotrowo str. 3, 60-965 Poznań, leszek.rozanski@gmail.com
}

\begin{abstract}
In medicine, many physical treatment procedures are bounded with the change of a tissue temperature. The paper presents comparative analysis of the body reaction on the various medical thermal stimulations. The vapors of liquid nitrogen, cold air and infrared lamp emitting $A, B, C$ waves were used to the analysis. In the analysis, the temperature distribution on the human palm was examined just before, just after and then after certain intervals of time. Only one palm was under the treatment, but it was observed that the thermal reaction appeared in both palms. In medical research more and more often complies infrared thermography systems for the purpose of showing the reaction of the organism on given impulse. Thank to the investigations, the procedures of thermal stimulations applied in rheumatology were optimized.
\end{abstract}

\section{Introduction}

The aim of the following paper is to present the possibility of thermographic systems application for the examination of thermal stimulations used in medicine. One of methods of the treatment of the rheumatoid arthritis (RA). is the physiotherapy. The field of physical therapy, which uses thermal energy for medical purposes is a thermotherapy. Heat therapy treatments are based on providing a certain amount of heat to the body, or by through their interaction causes extracting heat in the tissues [13]. Low themperature therapy is for getting the heat from the body. If temperatures are below $0^{\circ} \mathrm{C}$, it is named a cryother apy [16].

Local cryotherapy refers to a small body area e.g. palms or the knee [2]. A ventilation with a mixture of nitrogen vapours and cooled air (gas temperature at the outlet of the nozzle is about $\approx-1600^{\circ} \mathrm{C}$ ) and ventilation with cold air $\left(\approx-30^{\circ} \mathrm{C}\right)$ is used in the local cryotherapy [16]. Loc al cryotherapy is useful as an adjunct to a rehabilitation program for patients with RA because of its analgetic, anti-inflammatory efects and possibility of improving their ability to exercise [13]. Also the heat therapy is often used in a rehabilitation programme of rheumatoid arthritis patients. IR radiation is one of the most useful modalities for heating body parts with irregular contours (e.g. hands and feet) [15]. Currently, two types of IR radiators are used in physiotherapy. The standard IR radiator (SIR) that emits radiations of wavelength 770 $15000 \mathrm{~nm}$ and is mainly used for heating tissues. The water filter IRA (wIRA) that emits radiations of wavelength 770$1500 \mathrm{~nm}$ and is used to activate deeper tissues [13].

The positive effects of thermotherapy contains: increased blood flow owing to arteriolar and capillary dilatation $[4,8]$, muscle spasm relief [8], increased collagen extensibility [5,11], decreased joint stiffness in rheumatic disorders $[4,18]$ and nonpharmacological pain treatment (painkilling) [1]. For these reasons, thermotherapy and cryotherapy are commonly used as an introduction for physiotherapy, used as an introduction to kinesitherapy, to passive and active exercises $[3,12,13,14]$. The optimal time for which such exercises should be performed has not been precisely determined. The infrared measurement techniques allow for a faster and more precise monitoring of the cooling or warming process. The imaging of temperature distribution on the surface of the body makes it possible to evaluate the quality and correctness of the thermal impulse applied, as well as to determine if the response to the thermal stimulation used is adequate [16]. The use of the thermography systems allows us to determine the duration of response of the body to the used thermal pulse. The length of the time depends of an applied thermal impulse and his intensities. Thermographic studies allow to determine the optimal time to exercise for a specific case.

\section{Materials and methods}

The study included 97 patients with diagnosed RA. The aim of the research was to examined the reaction of the organism on the thermal stimulation intensity during the local cryotherapy procedure (47 patients average age \pm standard deviation [SD] 56,2 \pm 10,5y) and heat therapy - infrared radiation (IR-A, B, C) (50 patients, 56,2 \pm 9,3y) and duration of response of the organism to the applied stimulation.

In the first group in which treatment cryotherapy impulse was used, there were examined 23 processes of cooling with the use the peer of nitrogen Fig.1.b. (Temperature of the gas at the end of the nozzle was $\approx-160^{\circ} \mathrm{C}$ 
Fig.1.c.). Gas blow was done on both sides of hand from 10 to $15 \mathrm{~cm}$ distance. Treatments with cooling - vapors of nitrogen used ground device with 1000 I external container Fig.1.a.

a)

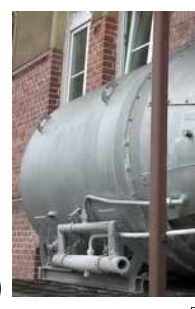

c)
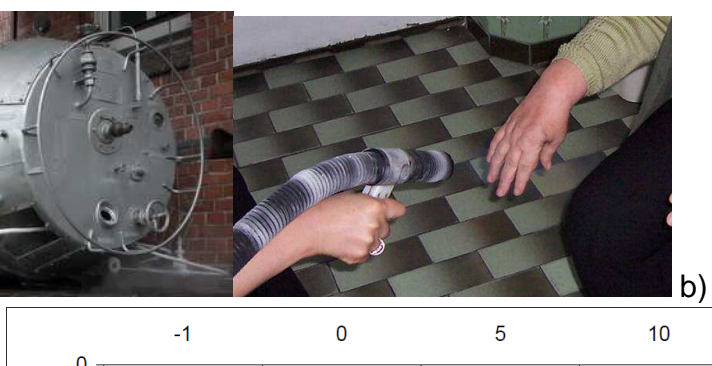

b)

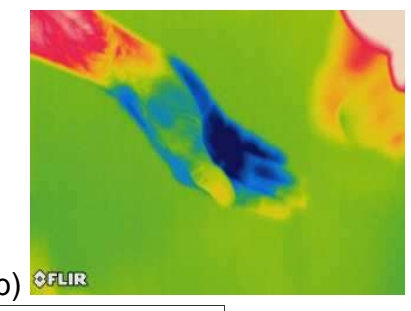

15

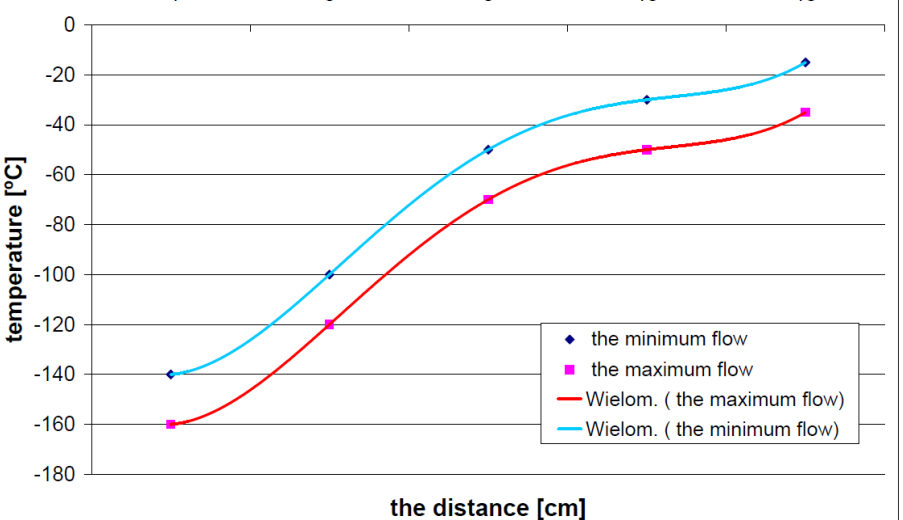

Fig. 1. Thermal stimulation - cooling with the use the peer of nitrogen

Secound group were 24 processes of cooling with the use of cold air Fig.2.b. (Temperature of the air at the end of $2-\mathrm{cm}$ size nozzle was $\approx-30^{\circ} \mathrm{C}$ Fig.2.c.). Gas blow was done on both sides of the hand from 4 to $6 \mathrm{~cm}$ distance. In the first minute of cold air treatment, there was $1000 \mathrm{l} / \mathrm{min}$ blow output in following $2 \mathrm{~min} 800 \mathrm{l} / \mathrm{min}$. Treatments with cooling - cold air used Cryo5 device (Zimmer-Germany) Fig.2.a.

The time of one thermal stimulation in both cases was 3 min.

a)
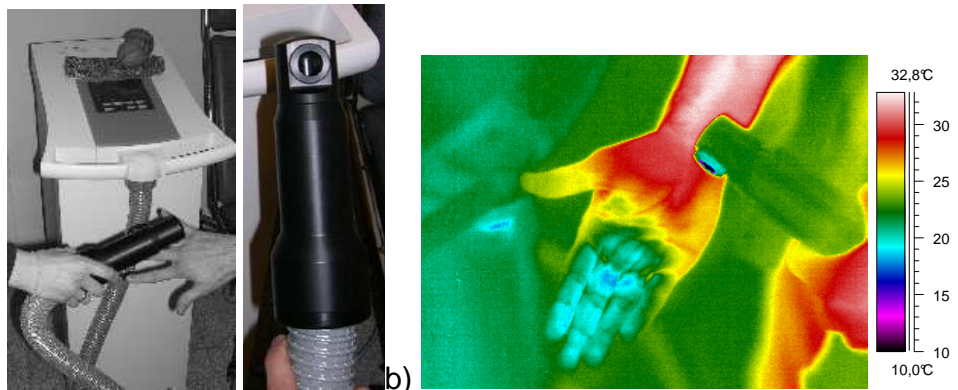

c)

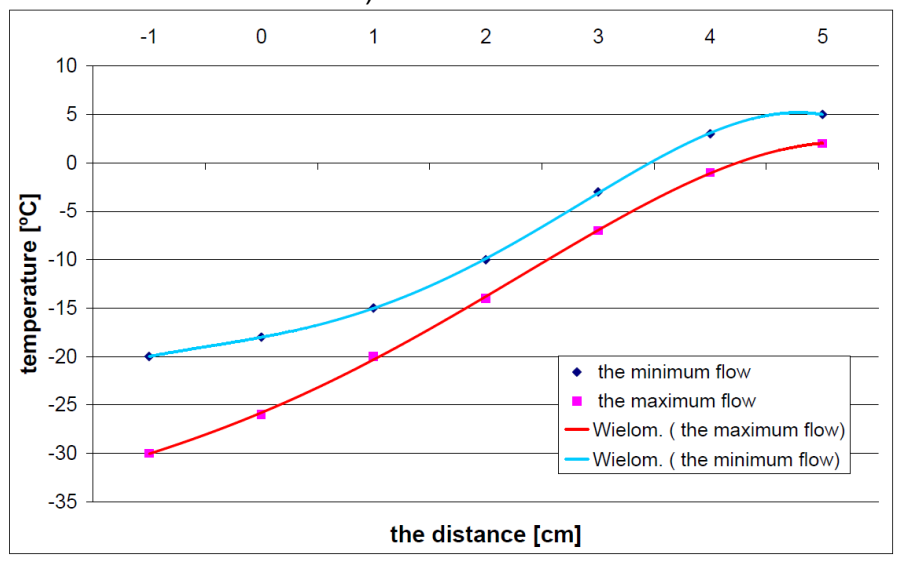

Fig. 2. Thermal stimulation - cooling with the use of cold air 
In the last group in which the SIR radiator Lumina and $375 \mathrm{~W}$ power $\left(240 \mathrm{~mW} \mathrm{~cm}{ }^{-2}\right)$, emitting radiation in the ranges IR-A,B,C was used, the time of the treatment was 15 min. Fig.3. IR treatment was applied to all patients on the back side of the hand. Similarly as in previous cases only one hand was treated a thermal stimulation with the IR lamp placed perpendicularly at $30 \mathrm{~cm}$ from the treatment surface. The other hand was not exposed to the IR radiation.
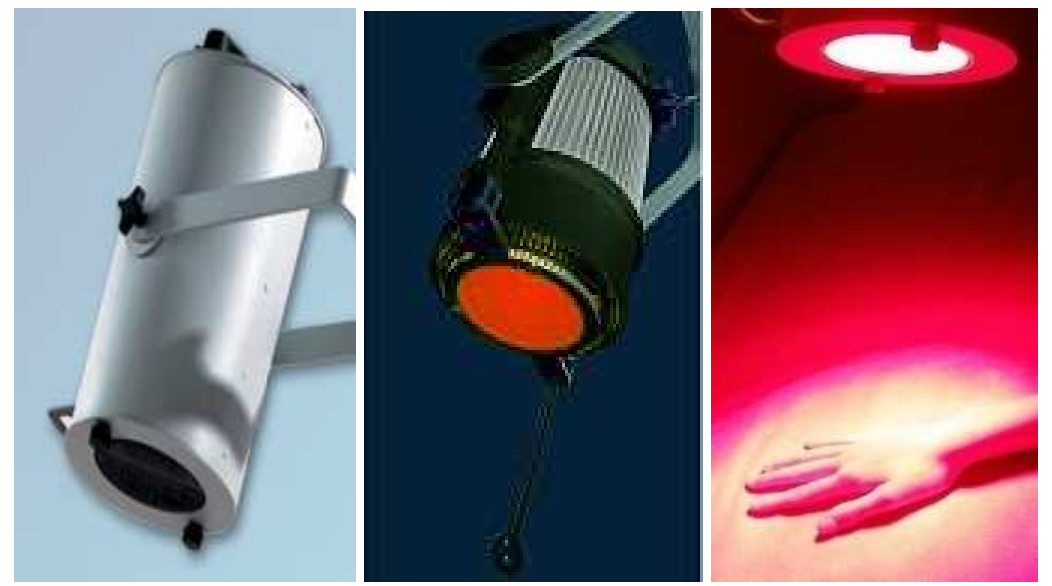

Fig. 3. SIR radiator

Thermography evaluation was accomplished by ThermaCAM SC 2000 and ThermaCAM SC 640 produced by FLIR and ThermaCAM Reporter program was used. It was assumed that skin emissivity is $0,98[6,7,9,19]$. Each patient had taken the thermogram of both hands. The thermograms were taken before the treatment, immediately after, and after $5,15,30,45,60,120$ minutes and for cryotherapy also after 180 minutes of ending the treatment. The treatment was done only on one hand in case of each patient.

Measurements were performed with special attention given to ensure the replicability of climatic conditions of all tests. The temperature in the room was maintained about $21.5 \pm 0.5^{\circ} \mathrm{C}{ }^{\circ} \mathrm{C}$, with humidity $31 \pm 2 \%$. All ex ternal sources of heat were separated and there was no air movement. The acclimation of patient (body temperature to stabilize) lasted for 15 minutes and took place in a room with similar conditions, and between each measurement (after 5, 15, 30, 45, 60, 120 minutes and for cryotherapy also after 180 minutes of ending the treatment) patient waited also in this room. During the day of the research patients were not allowed to smoke, drink alcohol or cofee and use other stimulants. Hands were washed and skin was degreased (cream or ointment was forbidden). They had avoided any physical exertion, except for normal daily activities. Rubbing palm or having hands in pockets was also forbidden. The thermograph camera was placed perpendicular to the horizontal surface on which an insulating mat specially prepared beforehand was placed and on which the patients placed their hands. A distance between the camera and the surface was about $1 \mathrm{~m}$. Pictures of dorsal sides of both hands were taken simultaneously. The area which were to be analyzed was limited by the markers which were made of aluminum foil. Fig.4. On the thermal image Fig.4 it is visible also the blackbody model (temperature standard below the palm). The use of the blackbody molel allows to reduce the uncertainty of thermographic measurement carried out under laboratory conditions to app. $0,5^{\circ} \mathrm{C}[10,17]$.

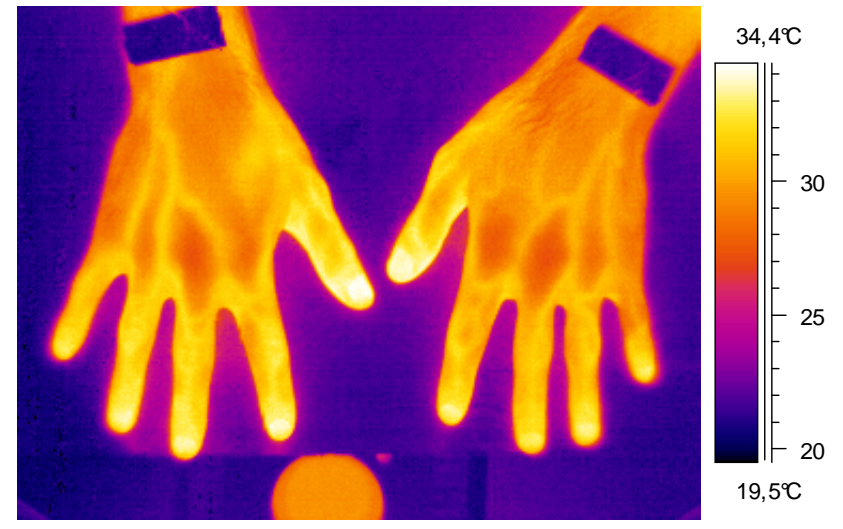

Fig. 4. IR-image sample before thermal stimulation (visible markers and black body) 


\section{Results}

Before the treatment, no significant differences were observed between skin surface temperatures (baseline temperature) in both groups of cooling processes and in group of warming process.

The Response of the organism to thermal stimulation with liquid nitrogen vapors, cool air and heat therapy infrared radiation (IR-A, B, C) presents charts Fig.5 for treatment hand and Fig.6. for not treatment hand, the value of Standard Deviation is in table 1.

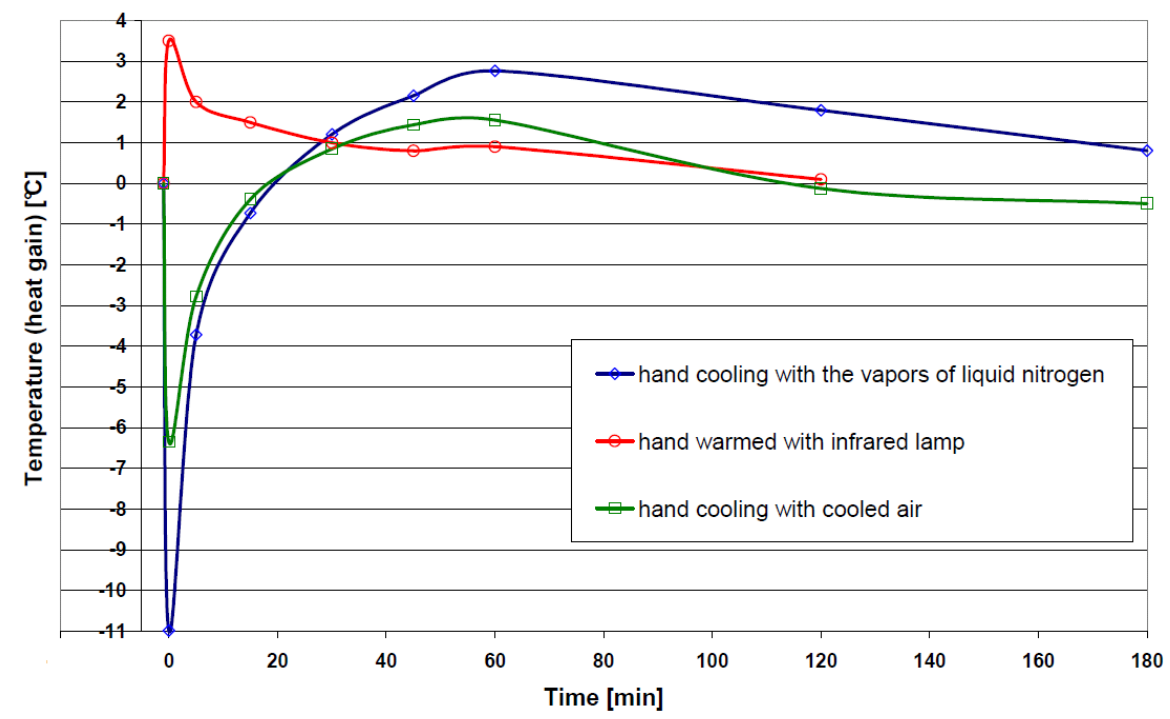

Fig. 5. Response of the organism to the thermal stimulation for hand treatment of thermal impulse

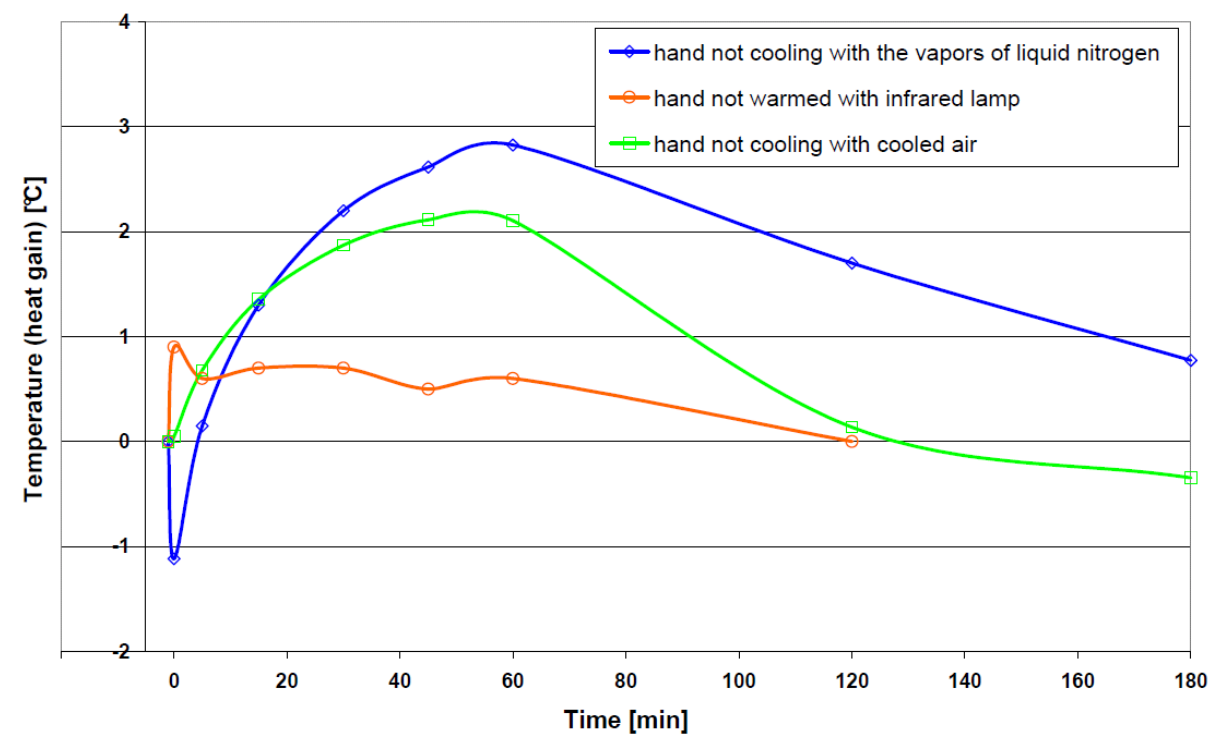

Fig. 6. Response of the organism to the thermal stimulation for hand not treatment of thermal impulse

The mean hand surface temperatures, immediately after thermal stimulation based on IR treatment significant increase $3,5 \pm 1.2^{\circ} \mathrm{C}$. For the not heated hand (IR t reatment), immediately after thermal stimulation increase $0,9 \pm 1,8^{\circ} \mathrm{C}$ then started decrease for about 120 min (similarly as the stimulated palm).

The mean hand surface temperature of hand cooling with the vapors of liquid nitrogen decrease $11,0 \pm 2.2^{\circ} \mathrm{C}$ and for hand not cooling with the vapors of liquid nitrogen decrease $1,1 \pm 1,9^{\circ} \mathrm{C}$. In the group cooling with the vapors of 
liquid nitrogen nitrogen, 1 min after the treatment, skin temperature of contralateral hand (without stimulation) decreased significantly and after that started increasing. About 5 minutes after the treatment, skin temperature reached the baseline temperature and still increase, after $120 \mathrm{~min}$. started to decrease

The mean hand surface temperature of hand cooling with the cooled air decrease $6,4 \pm 2.2^{\circ} \mathrm{C}$ and for han $\mathrm{d}$ not cooling with the cooled air increase $0,1 \pm 2,3^{\circ} \mathrm{C}$. I $\mathrm{n}$ the group cooling with the cooled air, skin temperature of contralateral hand didn't decrease below baseline in any time of measurement, and significant increase in skin temperature above 60 min after that started decreasing.

Table 1. The value of Standard Deviation concerning to average temperature surface of hand in reaction on stimulations $[\mathscr{C}]$

\begin{tabular}{|l|c|c|c|c|c|c|}
\hline & $\begin{array}{c}\text { hand cooling } \\
\text { with the vapors } \\
\text { of liquid nitrogen }\end{array}$ & $\begin{array}{c}\text { hand not } \\
\text { cooling with } \\
\text { the vapors of } \\
\text { liquid nitrogen }\end{array}$ & $\begin{array}{c}\text { hand cooling } \\
\text { with the cooled } \\
\text { air }\end{array}$ & $\begin{array}{c}\text { hand not } \\
\text { cooling with } \\
\text { the cooled air }\end{array}$ & $\begin{array}{c}\text { hand IR } \\
\text { treatment }\end{array}$ & $\begin{array}{c}\text { hand not } \\
\text { IR } \\
\text { treatment }\end{array}$ \\
\hline before & 1,8 & 1,7 & 2,3 & 2,3 & 1,9 & 2,1 \\
\hline immediately after & 2,2 & 1,8 & 2,2 & 2,3 & 1,2 & 1,8 \\
\hline 5 & 3,0 & 2,0 & 2,7 & 2,4 & 1,2 & 2,0 \\
\hline 15 & 3,1 & 1,9 & 3,1 & 2,6 & 1,5 & 2,1 \\
\hline 30 & 2,7 & 2,0 & 3,0 & 2,5 & 1,8 & 2,0 \\
\hline 45 & 2,5 & 2,0 & 3,0 & 2,6 & 1,9 & 2,0 \\
\hline 60 & 2,5 & 2,1 & 2,9 & 2,6 & 2,0 & 2,1 \\
\hline 120 & 2,2 & 2,2 & 2,3 & 3,1 & 1,8 & 2,0 \\
\hline 180 & 2,5 & 2,4 & 3,5 & 3,4 & & \\
\hline
\end{tabular}

This study compare effect of cooling stimulation ( $3 \mathrm{~min}$. application) of vapors of liquid nitrogen and cold air, and warming stimulation of SIR on hand skin temperature of RA patients. On the ground graphs Fig.5, Fig.6. one can observe the reaction of the organism on given thermal impulse and make analyses his intensity and the length the duration.

\section{Conclusions}

Thermography is a useful measurement technique in analysing thermal reaction of the organism on the thermal stimulation what was shown by above research. It was revealed that the stimulus produced by liquid nitrate vapors is much stronger thermal stimulation than the impulse produced by cool air. Temperature of the surface of the palm changes after IR treatment, which is indicative of the pattern of blood flow. Directly after the treatment the biggest increase (hand warmed) and the biggest decrease (hand cooled) and then about 5 minutes after the treatment of cold temperature of skin increase above the baseline temperature in hand surface temperature was observed. At the time it is the optimal time for exercise in the process of the rehabilitation persons diseased on rheumatoid arthritis. A consensual reaction in response to thermal stimulations (cooling and warming) was also observed.

\section{REFERENCES}

[1] R9. Chung, W., S. Xu, A. Eken and J. He (2009) Current status of complementary and alternative medicine in the treatment of rheumatic disease pain. Curr. Rheumatol. Rev. 5, 194-198.

[2] GABRYŚ M. S., POPIELA A. (red.), Krioterapia w medycynie, Wydawnictwo Medyczne Urban \& Partner, Wrocław. 2003

[3] KORMAN P., STRABURZYŃSKA-LUPA A., ROMANOWSKI R., TRAFARSKI A., 2011 Temperature changes in rheumatoid hand treated with nitrogen vapors and cold air. Journal Article: Rheumatology International 09/2011; DOI: $10.1007 / \mathrm{s} 00296-011-2078-5$

[4] R10. Lehmann, J. F., C. G. Warren and S. M. Scham (1974) Therapeutic heat and cold. Clin. Orthop. Relat. Res. 99, 207- 245.

[5] R12. Lehmann, J. F., A. J. Masock, C. G. Warren and J. N. Koblanski (1970) Effect of therapeutic temperatures on tendon extensibility. Arch. Phys. Med. Rehabil. 51, 481-487.

[6] MADURA H. (red.), Pomiary termowizyjne w praktyce, Wyd. PAK, Warszawa 2004.

[7] MINKINA W., Pomiary termowizyjne - przyrządy i metody, Wydawnictwo Politechniki Częstochowskiej 2004.

[8] R11. Nadler, S. F., K. Weingand and R. J. Kruse (2004) The physiologic basis and clinical applications of cryotherapy and thermotherapy for the pain practitioner. Pain Physician 7, 395- 399.

[9] NOWAKOWSKI A. (red.), Postępy termografii - aplikacje medyczne, Wydawnictwo Gdańskie, 2001 
[10] S. Poloszyk and L. Różański. Kształtowanie właściwości metrologicznych systemów diagnostyki termograficznej. Pomiary Automatyka Kontrola, 4, (2002), 36-39.

[11] R13. Robertson, V. J., A. R. Ward and P. Jung (2005) The effect of heat on tissue extensibility: A comparison of deep and superficial heating. Arch. Phys. Med. Rehabil. 86, 819-825.

[12] Rutkowski Radosław, Straburzyńska-Lupa Anna, Korman Paweł, Romanowski Wojciech, Raglewska Patrycja, Konarska Agata, Gizińska Małgorzata, Hurnik Elżbieta, Czubaszewski Łukasz. Temperature distribution in rheumatoid hand after standard infrared treatment Trends in Sport Sciences 2013 : 20 (1) , 62-65; bibliogr. 24 poz p-ISSN: 2299-9590

[13] Rutkowski Radosław, Straburzyńska-Lupa Anna, Korman Paweł, Romanowski Wojciech, Gizińska Małgorzata. Thermal Effectiveness of Different IR Radiators Employed in Rheumatoid Hand Therapy as Assessed by Thermovisual Examination Photochemistry and Photobiology 2011 (87) , 1442-1446 p-ISSN: 0031-8655 eISSN: 1751-1097

[14] STRABURZYŃSKA-LUPA A., STRABURZYŃSKI G, Fizjoterapia, Wydawnictwo Lekarskie PZWL 2003.

[15] R17. Tepperman, P. S. and M. Devlin (1986) The therapeutic use of local heat and cold. Can. Fam. Physician 32, 1110-1114.

[16] TRAFARSKI A., RÓŻAŃSKI L., STRABURZYŃSKA-LUPA A., KORMAN P., 2008, The Quality of Diagnosis by IR Thermogrphy as a Function of Thermal Stymulation in Chosen Medical Applications. 9th International Conference on Quantitative InfraRed Thermography July 2-5, 2008, Kraków. Studio Poligraficzne M.COLOR, Łódź, 2008, ss. 157-164

[17] C. Vincent, M. Szubert, R. Dębowska, K. Bazela, I. Eris, L. Różański, M. Stroiński, Z. Jaskólska and A. Duszyńska. Zastosowanie termografii w diagnostyce cellulite. Dermatologia Kosmetyczna, 2(43) (2006) 85-89.

[18] R5. Vliet Vlieland, T. P. M. (2003) Rehabilitation of people with rheumatoid arthritis. Best Pract. Res. Clin. Rheumatol. 17, 847-861.

[19] B. Więcek and S. Zwolenik. Termografia jako nieinwazyjna metoda diagnostyki w medycynie. Możliwości i osiagnięcia. III Światowe Targi Liderów Nowoczesnej Technologii MEDYCYNA'99, Łódź. Annales Academiae Medicae Lodzensis (40) (2000) 